\title{
Evaluation of Serum Ferritin in Hospitalized Patients with COVID-19 as A Potential Biomarker for Assessing COVID-19 Severity
}

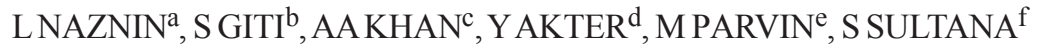

\begin{abstract}
:
Introduction: Corona virus disease 2019 (COVID-19), caused by severe acute respiratory syndrome coronavirus type 2 (SARS-CoV-2), has become global pandemic. Proinûamatory mediator, serum ferritin is reported to be elevated significantly by different studies in COVID-19. Our study was aimed to find whether serum ferritin level can be employed as a biomarker to assess the disease severity in COVID-19 cases.
\end{abstract}

Methods: This cross sectional observational study was carried out at Armed Forces Institute of Pathology (AFIP), a tertiary referral laboratory between 15 March 2020 and 15 June 2020. Total 2418 hospitalized RT-PCR confirmed COVID19 patients from Combined Military Hospital (CMH) were included in our study. Serum ferritin was measured by electrochemiluminescence immunoassay and was compared between the severe and non-severe groups. P-value $<$ 0.05 was considered statistically significant.

Results: Total patients were 2418, among them 337 (13.9\%) from intensive care unit (ICU) and 2081 (86.1\%) from nonICU. Median age and IQR were 60.5 (51.5-68.0) years in ICU patients versus 38.0 (28-46.1) years in non-ICU patients

Introduction:

Corona virus disease 2019 (COVID-19), first identified in Wuhan City, Hubei Province, China is caused by

a. Colonel Lubna Naznin, Classified Specialist in Pathology, AFIP, Dhaka Cantonment.

b. Major General Susane Giti, Classified Specialist in Pathology, Commandant, AFIP, Dhaka Cantonment.

c. Brig Gen Arif Ahmed Khan, Classified Specialist in Pathology, AFIP, Dhaka Cantonment.

d. Brig Gen Yasmin Akter, Classified Specialist in Pathology, AFMI, Dhaka Cantonment.

e. Brig Gen Mimi Parvin, Classified Specialist in Pathology, AFMC, Dhaka Cantonment.

f. Lt Col Sarmin Sultana, Classified Specialist in Pathology, AFMC, Dhaka Cantonment.

Address of Correspondence: Colonel Lubna Naznin, Classified Specialist in Pathology, AFIP, Dhaka Cantonment. Email: lubna101000@gmail.com, Mobile: 01769016626

Receive: 21 September, 2020

Accept: 10 June, 2021 (p < 0.0001$)$. Most $(86.8 \%)$ patients were males; $82.8 \%$ in ICU and $87.5 \%$ in non-ICU. Serum ferritin was significantly higher $(p<0.0001)$ in ICU patients; median and IQR was 952.8 (529.9 - 1520.5) $\mathrm{ng} / \mathrm{mL}$ versus 254.2 (156.1 - 441.9) $\mathrm{ng} / \mathrm{mL}(\mathrm{p}<0.0001)$ in non-ICU patients. Serum ferritin, at cut off value (COV) $<550 \mathrm{ng} / \mathrm{mL}$ had sensitivity $82.36 \%$ and specificity $73.59 \%$ for categorization of COVID-19 cases as non-severe. Comparison of proportions of ICU and non-ICU patients was found highly significant ( $p<0.0001$ at $95 \%$ confidence interval) with this cut off value.

Conclusions: Serum ferritin level was significantly high among COVID-19 patients requiring ICU admission than non-ICU cases. Serum ferritin may be used for categorizing COVID-19 patients. Cut off value $550 \mathrm{ng} / \mathrm{mL}$ can be meaningfully used for this categorization, above which should be considered severe and need more careful monitoring.

Key Words: COVID-19, SARS-CoV-2, Ferritin, Disease Severity, $I C U$

(J Bangladesh Coll Phys Surg 2021; 39: 220-224) DOI: https://doi.org/10.3329/jbcps.v39i4.55942

severe acute respiratory syndrome corona virus type 2 (SARS-CoV-2). ${ }^{1}$ This COVID-19 was officially stated pandemic on the $11^{\text {th }}$ March 2020 by the World Health Organization (WHO). ${ }^{1}$ WHO marked six-month anniversary of the COVID-19 outbreak on 29 June 2020 coincides with reaching 10 million cases and 500,000 deaths. $^{2}$ As of 27 July 2020, 06:00 GMT, COVID-19 update revealed worldwide cases confirmed 16,114,449 and deaths confirmed 646,641 over the 216 countries or territories. $^{3}$

This COVID-19 is characterized by highly variable clinical presentation; fever, cough, malaise; viral pneumonia; respiratory failure, heart failure, multi-organ dysfunction and death etc. ${ }^{1}$ Unremitting fever, hyperferritinemia and hyper-inûammatory process with massive release of pro-inûammatory cytokines are evident in severe COVID-19 has similarity to hyperferritinemic syndrome. ${ }^{4}$ This syndrome embraces 
adult onset still's disease (AOSD), systemic juvenile idiopathic arthritis (SJIA), secondary hemophagocytic lymphohistiocytosis (sHLH), catastrophic anti phospholipid syndrome (cAPS), and septic shock. ${ }^{4}$ Hyperferritinemia is a common feature in all of these conditions. ${ }^{6}$

Ferritin, an iron storage protein has critical role in iron homeostasis. Apoferritin, the iron-free form of this protein forms a roughly spherical shell of 24 subunits within which ferric iron remains stored. The subunits are of two types, termed $\mathrm{H}$ and $\mathrm{L}$. The ratio of these subunits varies widely depending on tissue type and can be modified under inflammatory and infectious conditions. ${ }^{7}$

The heavy H-subunit is primarily responsible for the ferroxidase activity required for the conversion of ferrous to ferric form for internalization and sequestration of iron in the ferritin complex, whereas the light L-subunit facilitates the storage of iron into the ferritin core. ${ }^{7,8}$ Majority of serum ferritin is immunologically related to ferritin L-subunit. ${ }^{7}$

Serum ferritin is a surrogate marker of iron status; is also elevated in oxidative stress and inflammation irrespective of iron status, and also in liver disease, decreased lung function and malignancy. 7,9,10 This inflammatory marker has been reported to be significantly associated with the high risk of the development of severe COVID-19. ${ }^{9}$

Inflammatory responses triggered by rapid viral replication of SARS-CoV-2 and cellular destruction recruit macrophages and monocytes that induce the release of cytokines and chemokines. ${ }^{11}$ These cytokines and chemokines then attract immune cells and activate immune responses, lead to cytokine storms. $4,9,12$ Cytokines and chemokines increased in plasma in COVID-19 are IL-1 ${ }^{2}$, IL-2, IL-4, IL-7, IL-10, IL-12, IL-13, IL-17, GCSF,IFN- ${ }^{3}$, TNF, pro-inflammatory IL-6, IP-10, macrophage inflammatory protein $1 \pm(\mathrm{MIP} 1 \pm), \mathrm{MIP}^{2}$ and MCP. ${ }^{4,11}$ Defective immune response leads to further accumulation of immune cells in the lungs, cause overproduction of pro-inflammatory cytokines. It eventually damages the lung infrastructure along with the resultant cytokine storm circulates to other organs and leads to multi-organ damage. In addition, nonneutralizing antibodies produced by B cells may enhance SARS-CoV-2 infection through antibodydependent enhancement (ADE), further exacerbates organ damage. ${ }^{11}$ Speciûc genetic susceptibility also causes exaggeration of such cytokines release in severe COVID-19. Pro-inûammatory mediators including serum ferritin are found elevated significantly in blood in these COVID-19 patients. $^{4}$

The aim of the study was to compare the serum ferritin status in between severe and non-severe COVID-19 patients and to find its usefulness with a cut off value for categorization of COVID-19 cases.

\section{Methods:}

This observational cross sectional study was carried out at Armed Forces Institute of Pathology (AFIP), a tertiary referral laboratory between 15 March 2020 and 15 June 2020. Total 2418 patients with COVID-19 hospitalized patients in CMH (Combined Military Hospital) were enrolled in our study irrespective of clinical presentation, age and sex. Patients were confirmed for COVID-19 by detecting SARS-CoV2 RNA by real-time polymerase chain reaction (RT-PCR) from their nasopharyngeal and oropharyngeal swabs at AFIP. Patients requiring ICU support were considered severe and those admitted in wards/cabins (non-ICU) were considered non-severe cases.

Serum Ferritin was measured in both the groups by using electrochemiluminescence immunoassay by Cobas 6000 analyzer (Roche, USA) with measuring range $0.5-2000$ $\mathrm{ng} / \mathrm{mL}$ or up to $100000 \mathrm{ng} / \mathrm{mL}$ with 50 fold dilution. Statistical analyses were performed by SPSS software version 20. Data were presented as number and percentages for categorical variables. Continuous variables were expressed as mean $\pm \mathrm{SD}$ as well as median \pm IQR (Inter Quartile Range). Serum ferritin levels were compared between the ICU and non-ICU groups by employing independent t-test; $p$-value $<\quad 0.05$ was considered statistically significant.

\section{Results:}

Among the total 2418 in-hospital patients, 337 (13.9\%) patients were from ICU care and 2081 (86.1\%) belonged to non-ICU care.

Mean \pm SD of age was $58.9 \pm 15.4$ years in ICU patients versus $37.7 \pm 13.0$ years in non-ICU patients. Median and inter quartile range was 60.5 years and $51.5-68.0$ years in ICU patients versus 36.0 years and 28.0- 46.1 years in non-ICU patients $(\mathrm{p}<0.0001)$. In this study, among the COVID-19 patients, $86.8 \%$ were male and $13.2 \%$ were female. Among the ICU patients $82.8 \%$ and among the non-ICU patients $87.5 \%$ were male versus $17.2 \%$ of ICU care and $12.5 \%$ of non-ICU care were female (Fig 1). 


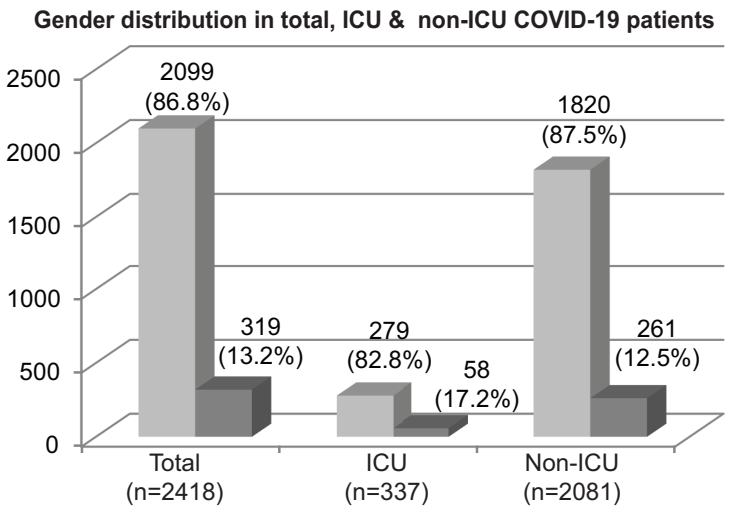

Fig.-1: Gender Distribution in Total, ICU \& non-ICU COVID-19 Patients
Serum Ferritin level in ICU versus non-ICU patients, mean was $1729.45 \mathrm{ng} / \mathrm{mL}$ versus $382.19 \mathrm{ng} / \mathrm{mL}$; median \& IQR was $952.8(529.9-1520.5) \mathrm{ng} / \mathrm{mL}$ versus 254.2 $(156.1$ - 441.9) $\mathrm{ng} / \mathrm{mL}(\mathrm{p}<0.0001)$ (Table I).

Considering sensitivity and specificity for different cut off values (COV) of serum ferritin, $\mathrm{COV}<550 \mathrm{ng} / \mathrm{mL}$ seems to be preferable for non-severe cases with sensitivity $82.36 \%$ and specificity $73.59 \%$ for categorization of COVID-19. (Table II). p-value for comparison of proportions of ICU and non-ICU patients was found highly significant $(\mathrm{p}<0.0001)$ at $95 \%$ confidence interval with this COV.

Table-I

Serum Ferritin in ICU \& non-ICU COVID-19 Patients

\begin{tabular}{lcccc}
\hline Serum Ferritin & $\begin{array}{c}\text { Total } \\
(\mathrm{n}=2418)\end{array}$ & $\begin{array}{c}\text { ICU Patients } \\
(\mathrm{n}=337)\end{array}$ & $\begin{array}{c}\text { Non-ICU Patients } \\
(\mathrm{n}=2081)\end{array}$ & p-value \\
\hline Mean $(\mathrm{ng} / \mathrm{mL})$ & 569.96 & 1729.45 & 382.19 & $<0.0001$ \\
Median (IQR) $(\mathrm{ng} / \mathrm{mL})$ & 289.4 & 952.8 & 254.2 & \\
& $(169.5-560.4)$ & $(529.9-1520.5)$ & $(156.1-441.9)$ & \\
\hline
\end{tabular}

Table-II

Different Cut off Values of Serum Ferritin with Sensitivity and Specificity for the Differentiation of ICU \& non-ICU Patients

\begin{tabular}{|c|c|c|c|c|c|}
\hline $\begin{array}{l}\text { Serum } \\
\text { Ferritin COV }\end{array}$ & $\begin{array}{c}\text { Frequency } \\
\text { among ICU } \\
\text { patients } \\
(\mathrm{n}=337)\end{array}$ & $\begin{array}{c}\text { Frequency } \\
\text { among Non- } \\
\text { ICU patients } \\
\quad(n=2081)\end{array}$ & $\begin{array}{c}\text { ICU }(\%) \text { Vs non-ICU } \\
(\%) \text { patients (p- } \\
\text { value) }\end{array}$ & $\begin{array}{l}\text { Sensitivity } \\
\text { for non- } \\
\text { ICU cases }\end{array}$ & $\begin{array}{l}\text { Specificity } \\
\text { for non- } \\
\text { ICU cases }\end{array}$ \\
\hline$<250 \mathrm{ng} / \mathrm{mL}$ & $30 / 337$ & $1025 / 2081$ & $\begin{array}{c}8.9 \% \text { vs } 49.2 \% \\
\quad(p<0.0001)\end{array}$ & $49.26 \%$ & $91.10 \%$ \\
\hline$<350 \mathrm{ng} / \mathrm{mL}$ & $45 / 337$ & $1370 / 2081$ & $\begin{array}{c}13.35 \% \text { vs } 65.8 \% \\
\quad(p<0.0001)\end{array}$ & $65.83 \%$ & $86.65 \%$ \\
\hline$<450 \mathrm{ng} / \mathrm{mL}$ & $71 / 337$ & $1572 / 2081$ & $\begin{array}{l}21 \% \text { vs } 75.5 \% \\
\quad(p<0.0001)\end{array}$ & $75.54 \%$ & $78.93 \%$ \\
\hline$<550 \mathrm{ng} / \mathrm{mL}$ & $89 / 337$ & $1714 / 2081$ & $\begin{array}{c}26.4 \% \text { vs } 82.4 \% \\
\quad(p<0.0001)\end{array}$ & $82.36 \%$ & $73.59 \%$ \\
\hline$<650 \mathrm{ng} / \mathrm{mL}$ & $109 / 337$ & $1801 / 2081$ & $\begin{array}{c}32.3 \% \text { vs } 86.5 \% \\
(p<0.0001)\end{array}$ & $89.65 \%$ & $67.66 \%$ \\
\hline$<750 \mathrm{ng} / \mathrm{mL}$ & $125 / 337$ & $1873 / 2081$ & $\begin{array}{c}37.1 \% \text { vs } 90 \% \\
(p<0.0001)\end{array}$ & $90.00 \%$ & $62.91 \%$ \\
\hline
\end{tabular}

* COV: Cut off value 


\section{Discussion:}

We found serum ferritin increased significantly in severe patients with median (IQR), $952.8(529.9-1520.5) \mathrm{ng} / \mathrm{mL}$ in compare to non-severe patients, 254.2 (156.1 - 441.9) $\mathrm{ng} / \mathrm{mL}(\mathrm{p}<0.0001)$ (Table I). It indicates serum ferritin can be used as a very effective and independent marker for assessment of severity of COVID-19. Increase in serum ferritin in bacterial and/or viral infection results from the release of iron from the reticulo-endothelial system, decreased ability of transporting ferritin in liver and spleen and increased synthesis and release of intracellular ferritin. Elevated serum ferritin can predict a poor outcome in hospitalized patients with influenza infection. ${ }^{13}$ Chen et al. reported that most patients (63\%) of COVID-19 had their serum ferritin beyond the upper reference limit. ${ }^{14}$ Bo Zhou et al in their study found, serum ferritin level was increased in both severe and very severe COVID-19 cases but was significantly elevated in very severe patients compared with that of severe patients; median $1006.16 \mathrm{ng} / \mathrm{ml}$ (IQR: 408.265 1988.25) vs $291.13 \mathrm{ng} / \mathrm{ml}$ (IQR: 102.1-648.42), respectively. ${ }^{13}$ In agreement with this, Fei Zhou et al study revealed serum ferritin was elevated in nonsurvivors compared with survivors throughout the clinical course, and increased with deterioration of illness. They found median (IQR) of serum ferritin $1435 \cdot 3$ (728.9-2000.0) in non-survivors versus 503.2 (264.0$921.5)$ in survivors $(p<0 \cdot 0001) .{ }^{15}$ A retrospective, multicenter study on 150 confirmed COVID-19 cases in Wuhan, China, observed elevated ferritin, mean $1297 \cdot 6$ $\mathrm{ng} / \mathrm{ml}$ in non-survivors vs $614.0 \mathrm{ng} / \mathrm{ml}$ in survivors $(p<0 \cdot 001)$, with elevated IL-6 ( $<<0 \cdot 0001)$ suggested that mortality might be due to virally driven hyperinflammation. ${ }^{16}$ Mehta et al ${ }^{16}$ recommended all patients with severe COVID-19 should be screened for hyperinflammation using laboratory trends including elevated ferritin for whom immunosuppression might improve critical and life-threatening illness. A total of 16 studies comprising 3962 patients with COVID-19 were included in a meta-analysis by Furong Zenga et al showed the non-severe group had lower levels for serum ferritin (Weighted Mean Difference $=-398.80 \mathrm{mg} / 1,95 \%$ $\mathrm{CI}=[-625.89,-171.71], \mathrm{P}<0.001)$, compared with the severe group. They recommended further research to find the positive correlation between serum ferritin level and the severity of COVID-19. ${ }^{9}$

In our study, median and inter quartile range of age was $60.5(51.5$ - 68.0) years In ICU patients and 36.0 (28-
46.1) years in non-ICU patients ( $p$ value $<0.0001$ ), was statistically highly significant. We observed older age was related to severity of the disease, is also supported by Zhou et al study. ${ }^{15}$

Most of our patients were males, in our study 2099 $(86.8 \%)$ were male, among them $1820(87.5 \%)$ were in non-ICU care and $279(82.8 \%)$ were in ICU care. Exact mechanism behind this is yet to establish. But, it can be assumed that immune-related genes of the whole genome are largely on $\mathrm{X}$ chromosome and female because of their two copies of $\mathrm{X}$ chromosomes have more pronounced innate and adaptive immunity for better response than male against COVID-19. ${ }^{17,18}$

Clinical features, other infection biomarkers and variable timing for ferritin estimations were not considered in this study were the limitations of our study.

\section{Conclusion:}

Severe COVID-19 (ICU cases) had significantly high ferritin levels in comparison with non-severe group (non-ICU cases). Serum ferritin level was related to the severity of COVID-19. Hence, serum ferritin might be used as a relatively available and prognostic decisive marker for categorization of COVID-19 effectively. Measurement of serum ferritin can contribute clinicians in management of such patients. Further research should go on to evaluate, either this high ferritin is an active pathogenic initiator or is a consequence of inûammation in COVID-19.

Conflict of interest:

The authors have no conflict of interest.

\section{Acknowledgments:}

We thank all the patients as well as the lab technologists of AFIP involved in specimen collection and technical jobs related to this study.

\section{Reference:}

1. Chen $\mathrm{T}, \mathrm{Wu} \mathrm{D}$, Chen $\mathrm{H}$, Yan W, Yang D, Chen $\mathrm{G}$ et al. Clinical characteristics of 113 deceased patients with coronavirus disease 2019: retrospective study. BMJ. 2020 https://doi.org/10.1136/bmj.m1091 PMid:32217556 PMCid:PMC7190011 368: m1091. Published online 2020 Mar 26. doi: 10.1136/bmj.m1091 https://doi.org/10.1136/ bmj.m1091 PMid:32217556 PMCid:PMC7190011

2. https://www.researchgate.net/post/The_sixmonth anniversary_of the_Corona_outbreak (accessed date 29 June 2020) 
3. https://www.who.int/docs/default-source/coronaviruse/ situation-reports/20200727-covid-19-sitrep-189. (accessed date 27 July 2020)

4. Ruscitti P, Berardicurti O, Di Benedetto P, Cipriani P, Iagnocco A, Shoenfeld Y et al. Severe COVID-19, Another Piece in the Puzzle of the Hyperferritinemic Syndrome. An Immunomodulatory Perspective to Alleviate the Storm. Front. Immunol. 2020; 11:1130. doi: 10.3389/ûmmu. 2020.01130. https://doi.org/10.3389/fimmu.2020.01130 PMid:32574264 PMCid:PMC7270352

5. Ramos-Casals M, Brito-Zeron P, Lopez-Guillermo A, Khamashta MA, Bosch X. Adult haemophagocytic syndrome. Lancet. 2014; 383: 1503-16. https://doi.org/ $10.1016 / \mathrm{S} 0140-6736(13) 61048-\mathrm{X}$

6. Karakike E, Giamarellos-Bourboulis EJ. Macrophage activation-like syndrome: a distinct entity leading to early death in sepsis. Front Immunol. 2019; 10: 55. https:// doi.org/ 10.3389/fimmu. 2019.00055 PMid:30766533 PMCid:PMC6365431

7. Knovich MA, Storey JA, Coffman LG, Suzy V. Torti SV. Ferritin for the Clinician. Blood Rev. 2009; 23(3): 95-104. doi:10.1016/j.blre.2008.08.001. https://doi.org/10.1016/ j.blre.2008.08.001 PMid:18835072 PMCid:PMC2717717

8. Kell BD, Pretorius E. Serum ferritin is an important inflammatory disease marker, as it is mainly a leakage product from damaged cells. Metallomics. 2014; 6: 748-773. https:/ /doi.org/10.1039/C3MT00347G PMid:24549403

9. Zenga F, Huangc Y, Guoa Y, Yina M, Chena X, Liang Xiaod et al. Association of inflammatory markers with the severity ofCOVID-19: A meta-analysis. International Journal of Infectious Diseases. 2020; 96:467-474. https://doi.org/ 10.1016/j.ijid.2020.05.055 PMid:32425643 PMCid:PMC 7233226

10. Lee J, Park Hk, Kwon M-J, Ham S-Y, Kim JM, Lim S-Y, et al. Decreased lung function is associated with elevated ferritin but not iron or transferrin saturation in 42,927 healthy Korean men: A cross-sectional study. PLoS ONE.
2020; 15(4): e0231057. https://doi.org/10.1371/journal. pone.0231057 PMid:32240239 PMCid:PMC7117746

11. Tay MZ, Poh CM, Rénia L, MacAry PA, Lisa FPN. The trinity of COVID-19: immunity, inflammation and intervention. Nature Reviews Immunology. June 2020; 20: 363-374. https://doi.org/10.1038/s41577-020-0311-8 PMid:32346093 PMCid:PMC7187672

12. Xu X, Han M, Li T, Sun W, Wang D, Fu B et al. Effective treatment of severe COVID-19 patients with tocilizumab. PNAS; May 2020; 117:10970-10975. https://doi.org/ 10.1073/ pnas.2005615117 PMid:32350134 PMCid: PMC 7245089

13. Zhou B, She J, Wang Y. Utility of Ferritin, Procalcitonin, and C - reactive protein in Severe Patients with 2019 Novel Coronavirus Disease; 2020. https://doi.org/10.21203/ rs.3.rs- $18079 / \mathrm{v} 1$

14. Chen N, Zhou M, Dong X, Qu J, Gong F, Han Y, et al. Epidemiological and clinical characteristics of 99 cases of 2019 novel coronavirus pneumonia in Wuhan, China: a descriptive study. Lancet. 2020; 395:507-13. https://doi.org/ 10.1016/S0140-6736(20)30211-7

15. Zhou F, Yu T, Du R, Fan G, Liu Y, Liu Z et al. Clinical course and risk factors for mortality of adult inpatients with COVID-19 in Wuhan, China: a retrospective cohort study. Lancet. 2020;395:1054-62 https://doi.org/ 10.1016/ S0140-6736(20)30566-3

16. Mehta P, McAuley DF, Brown M, Sanchez E, Tattersall RS, Manson J. COVID-19: consider cytokine storm syndromes and immunosuppression. Lancet. 2020; 395:1033-34. https://doi.org/10.1016/S0140-6736(20)30628-0

17. Bianchi I, Lleo A, Gershwin ME, Invernizzi P. The X chromosome and immune associated genes. Journal of Autoimmunity. 2012; 38:187-92. https://doi.org/10.1016/ j.jaut.2011.11.012 PMid:22178198

18. Klein SL, Flanagan KL. Sex differences in Immune responses. Nature Reviews Immunology. 2016; 16(10):626638. https://doi.org/10.1038/nri.2016.90 PMid:27546235 